to bear a vast knowledge of detail combined with unfailing judgment and soundness of inference.

Since the close of the War of 1914-18, Prof. Tallgren's publications dealing with the archæology and cultural history of Finland and adjacent regions of the northern tract have brought him an outstanding reputation as an international authority on the study of European prehistory. An even greater service to archæological studies has been rendered by his periodical publication, Eurasia Septentrionalis Antiqua, which he founded in 1926 and edited, contributing liberally to the contents himself until, in 1939, the action of the Soviet Government, by cutting his line of communications with Russia, deprived him of the material essential to the continuation of his studies and constrained him to stop publication (see NATURE, $144,971 ; 1939)$. This action of the Soviet followed Prof. Tallgren's account of conditions in Russia in his "Archæological Studies in Russia" (1936).

\section{Epidemiology of Evacuation}

IN his presidential address to the Section of Epidemiology and State Medicine of the Royal Society of Medicine on April 5, Dr. J. A. Glover, chief medical officer of the Board of Education, stated that in the evacuation carried out in Britain last autumn there were moved 1,270,000 persons, made up as follows : 734,883 school children, nearly all moved in the first two days before the beginning of war; (2) some 260,300 young children accompanied by (3) some 166,200 mothers and other adults ; and (4) 12,291 expectant mothers. All these persons were moved with punctuality and precision without a single casualty in four days. As regards the incidence of infectious disease, the record of the first four months was extraordinarily good. The cases of diphtheria and scarlet fever notified were only two thirds of those which occurred in the corresponding period of 1938, and the cases of poliomyelitis were only one third, although all these three diseases had their seasonal maxima in autumn and were diseases to which school children were particularly liable. There was a decline in notifications of puerperal pyrexia.

There had been small epidemics of enteric fever before evacuation took place, but notifications afterwards fell, and in November and December were well below those of 1938 . The expected epidemic of measles was not realized and particularly avoided the big cities, and especially London. The health record of evacuated special schools was very good. The comparative freedom from infectious disease was attributable to the careful preparations of the Ministry of Health, the good work of the medical and nursing services, the care of the foster parents and teachers, the general soundness of the environmental hygiene, and the splendid weather of the early autumn. Dr. Glover maintained that the general policy of dispersal in billets was preferable to that of concentration in camps, in view of the much greater risk of spread of disease in such concentrations of children. In conclusion, he stated that the evacuated child who remained in the reception areas benefited greatly in health.
National Union of Students :

London Medical Committee

Tre London Medical Students' Committee of the National Union of Students was formed shortly after the War began. The first important action which the committee took was to get the status of medical students defined by the Ministry of Health. Up to this time hospital authorities and the Ministry of Health both disclaimed responsibility. The position is now clearly that medical students have no obligations to the Ministry, and vice versa. A request was received recently from one of the northern universities that the London Committee should organize a conference on medical student life and work. The Committee is accordingly arranging a meeting to discuss the teaching of medicine and the methods of study, which, it is hoped, will be held in a Midland university in May. The conference will be divided into three main sections. The first part will be devoted to the pre-clinical student, the second to the clinical student, and the third to the newly qualified doctor.

There has been much discussion in the Press recently on reforms in medical education. Efficient teaching is no less necessary now than it was before the War ; in fact, with the prospect of courses being shortened, efficient teaching becomes even more necessary. The conference will therefore have two sessions on education in all its phases, and from the experience of delegates endeavour to formulate an improved scheme of medical teaching. This will be combined with an endeavour to assure to the newly qualified medical man adequate house appointments to make him fit to carry out his duties. Medical students have suffered as much as others from many recent hasty decisions, and the prompt response to attempts to cut out subjects (for example, pathology from the Conjoint Board Examination) from the curriculum has shown a very healthy feeling on the part of students that standards must not be lowered, and was perhaps instrumental in maintaining the standard of the curriculum. The medical practitioner has certain duties to the public, and therefore his qualifications must be such as to enable him to carry out these duties, whether in war-time or in the time of peace.

\section{Pharmacopcia Revision}

DR. C. H. HAmpshire, secretary of the Pharmacopoia Commission, gave an account of the work which is being done in preparation for a new "British Pharmacopœia" in a lecture delivered at an evening meeting of the Pharmaceutical Society on April 9. He confirmed that the Commission hopes to provide standards not only for crude drugs and chemicals but also for as many galenical preparations and compounded drugs as possible, adding that it is essential that standards for such substances should have due regard to the possible loss of active matter during manufacture and subsequent storage. The greater part of the lecture was devoted to an exposition of recommendations made by various committees for the inclusion of new substances in the 
next "Pharmacopœia". Dr. Hampshire exhibited specimens of thesé substances, classifying them in their appropriate groups. With regard to vitamins, he said the principal preparations of this group recommended for description are: Standardized concentrated solutions of vitamins $\mathbf{A}$ and $\mathrm{D}$; a vitaminized oil standardized to contain vitamins $A$ and $\mathrm{D}$ in the proportion contained in a good average specimen of cod liver oil ; halibut liver oil containing not less than 30,000 units of vitamin A per gram; and pure crystalline aneurine hydrochloride to replace the adsorbate of vitamin $B_{1}$, described in the "Addendum; 1936".

Dr. Hampshire explained the reasons for some of the proposed additions to the "Pharmacopœia". Thus mandelic acid and calcium mandelate are both in use in the treatment of urinary infections; sulphanilamide is recommended as the best known member of the sulphonamide group which is free from patent complications; parachlorometacresol is recommended for use as a bactericide in sterilizing solutions for injection, and as a bacteriostatic preservative in certain solutions. $\mathrm{He}$ said that the proposed inclusion of the sera and other biologically tested preparations is necessary in order to bring this section of the work of the "Pharmacopcia" up to date. In this field the "Pharmacopoia" is kept closely in line with the regulations under the Therapeutic Substances Act; the regulations provide for the control of biologically tested substances in Great Britain and Northern Ireland, while the "Pharmacopœia" extends the control to other parts of the British Empire in which the "Pharmacopœia". is accepted as a legal standard. The revision has included a full review of all analytical procedure described in the various monographs and in the appendixes. In two directions a considerable increase in analytical methods is proposed : $(a)$ the addition of new tests and assays for galenical preparations and compounded drugs; and $(b)$ the addition, in a number of instances, of assays for the alkaloidal content of salts of various alkaloids.

\section{Astronomical Investigations of Horrox}

Prof. F. J. M. Stratron has published a very interesting and full account of the work of Horrox (Occas. Notes Roy. Astro. Soc., No. 7 ; 1939). To many astronomers, Horrox's fame rests almost entirely on his observation of the transit of Venus on November 24, 1639 (O.S.), his own calculations having shown an error in the Rudolphine tables, and also that a transit should take place on the above date. This was only a small part of his work, for, in addition to improving the tables then in existence, he was the first to show that the moon's orbit around the earth is an ellipse, the earth being at a focus. An excerpt from some of his writings at the age of eighteen shows that he anticipated Newton in connecting the movements of the planets with that of a body falling to the earth. The motion of the line of apses was explained by Horrox as due to the disturbing effect of the sun, and he was able to illustrate the idea by a simple pendulum experiment. In addition to his explanation of other difficulties connected with the motion of the moon, he detected the long inequalities in the opposite sense in the motions of Jupiter and Saturn, and he showed that comets move in elliptic orbits around the sun.

Although he undertook regular observations of the tides, no published work of Horrox on this subject survives, but he expressed the hope to Crabtree less than a month before his death that he would shortly detect the secret of the tides. Kepler's value of the distance of the sun was 3,500 times the earth's radius, and Horrox gave the value as 15,000 , that is, about two thirds the correct value. It is amazing that Newton adopted 5,000 fifty years later, instead of using Horrox's 15,000. When it is remembered that these results were obtained by one who had only attained the age of twenty-one and that he was practically self-taught and unaided, it is not surprising that astronomers have kept his name in affectionate remembrance for hundreds of years. What fields would Horrox have explored if he had not died at the early ago of twenty-two in 1641 , the year before Newton was born? In 1874, when a transit of Venus occurred, a memorial was erected to him in Westminster Abbey, and over the monument are-carved the words in which Horrox reported that he had abandoned the observations of the sun to carry out his spiritual duties in the Church.

\section{King Psusennes's Tomb at Tanis}

Now that the jewellery associated with the sarco. phagus of King Psusennes at San el Hagar, in Lower Egypt, has been removed to the Cairo Museum, further details are becoming available which serve to indicate more fully the cultural and historical significance of the find. The similarity in the circumstances of discovery with those of the discovery of the tomb of Tutankhamen is striking. For years Lord Carnarvon and Howard Carter excavated in the Valley of the Kings without notable success until they made their great discovery. At Tanis, which had already been explored by both Mariette and Petrie with indifferent results, Prof. Montet pursued his investigation of the relics of the obscure Twentyfirst and Twenty-second Dynasties for nine years from 1929, before last year he made the remarkable discovery of the gold and silver sarcophagus of King Shishak, of the Twenty-second Dynasty, in the otherwise rifled tomb of King Psusennes, of the Twenty-first Dynasty.

The tomb of Psusennes, son of Smendes, founder of the Twenty-first or Tanite Dynasty, is situated in the temple of Rameses. It is of solid rose granite, it is stated in a communication from the corres. pondent of The Times in the issue of April 6, and is a few metres underground. Entrance is at present down a shaft about four metres deep through rock and sand. A small anteroom leads by a short passage, about two metres long, and hewn through solid granite, into the funerary chamber. This is also small, measuring only seven metres long by about three metres wide and high. The sarcophagus itself 